\title{
Biyouyanagin A, an Anti-HIV Agent from Hypericum chinense L.
}

\section{var. salicifolium}

\author{
Naonobu Tanaka ${ }^{\dagger}$, Mamoru Okasaka $^{\dagger}$, Youko Ishimaru ${ }^{\dagger}$, Yoshihisa Takaishi ${ }^{\star}, \dagger$, Mitsunobu \\ Sato $\ddagger$, Masato Okamoto $\ddagger$, Tetsuya Oshikawa $¥$, Sharif Uddin Ahmed $\ddagger$, L. Mark Consentino§, \\ and Kuo-Hsiung Leell \\ Faculty of Pharmaceutical Sciences, University of Tokushima, Shomachi 1-78, Tokushima, \\ 770-8505, Japan, School of Dentistry, University of Tokushima, Kuramoto-cho, Tokushima \\ 770-8504, Japan, BBI-Biotech Research Laboratories, Perry Parkway, Gaithersburg, Maryland \\ 20877, and Natural Products Laboratory, School of Pharmacy, University of North Carolina, Chapel \\ Hill, North Carolina 27599
}

\begin{abstract}
A structurally unique hydrophobic compound, biyouyanagin $\mathrm{A}$, was isolated from the $\mathrm{MeOH}$ extract of the leaves of Hypericum chinense L. var. salicifolium. The structure of biyouyanagin A was elucidated on the basis of spectroscopic evidence. Biyouyanagin A showed a significant activity against HIV and inhibited cytokine production.
\end{abstract}

The recent widespread interest in the antidepressant activity of Hypericum perforatum (St. John's wort) has inspired the investigation of secondary metabolites from other Hypericum species. ${ }^{1}$ The genus Hypericum, which are distributed widely in temperate regions, have been used as traditional medicines in various parts of the world. In Japan, H. chinense L. var. salicifolium (Biyouyanagi in Japanese) is used as a folk medicine for treatment of female disorders. ${ }^{2}$

Antibacterial acylphloroglucinols and spirolactones were also isolated from this species. ${ }^{3}$ As a part of a program to discover new bioactive natural products from plants, we have examined the $\mathrm{MeOH}$ extract from the leaves of $H$. chinense and isolated a unique hydrophobic compound named biyouyanagin $\mathrm{A}$, which contains sesquiterpene, cyclobutane, and spirolactone moieties. Biyouyanagin A showed a significant activity against HIV and inhibited cytokine production. In this paper, we report isolation, structural elucidation, and biological evaluation of biyouyanagin $\mathrm{A}$.

Dried leaves of $H$. chinense L. var. salicifolium $(1.48 \mathrm{~kg}$ ) were extracted with $\mathrm{MeOH}$. The $\mathrm{MeOH}$ extract $(632.7 \mathrm{~g})$ was partitioned with $n$-hexane and $\mathrm{H}_{2} \mathrm{O}$, and the $n$-hexane fraction $(92.6 \mathrm{~g})$ was subjected to repeated column chromatography to give biyouyanagin A.

Biyouyanagin A (1) was obtained as a colorless oil, $[\alpha]_{\mathrm{D}}-240.0\left(\mathrm{CHCl}_{3}, c 0.5\right)$. The IR spectrum of 1 showed absorption bands of two carbonyl groups $\left(1792,1743 \mathrm{~cm}^{-1}\right)$. The ${ }^{1} \mathrm{H}$

\footnotetext{
* To whom correspondence should be addressed. Tel: 81-88-6337275. Fax: 81-88-6339501. takaishi@ph.tokushima-u.ac.jp.

$\dagger$ Faculty of Pharmaceutical Sciences, University of Tokushima.

\$School of Dentistry, University of Tokushima.

$\$$ BBI-Biotech Research Laboratories.

\|School of Pharmacy, University of North Carolina.
}

Supporting Information Available: Experimental section, plant material, extraction, isolation, and spectral data of biyouyanagin A

(1). This material is available free of charge via the Internet at http://pubs.acs.org. 
NMR showed the presence of a benzene ring $\left[\delta_{\mathrm{H}} 7.26-7.37(5 \mathrm{H}, \mathrm{m})\right]$, a 1-substituted ethylene moiety $\left[\delta_{\mathrm{H}} 5.24(1 \mathrm{H}, \mathrm{dd}, J=17.6,11.2), 4.80(1 \mathrm{H}, \mathrm{d}, J=11.2), 4.62(1 \mathrm{H}, \mathrm{d}, J=17.6)\right]$, two olefinic protons $\left[\delta_{\mathrm{H}} 5.46(1 \mathrm{H}, \mathrm{m}), 5.11(1 \mathrm{H}, \mathrm{brt}, J=5.6)\right]$, one oxygenated methylene group $\left[\delta_{\mathrm{H}} 4.71,3.98\right.$ (each $1 \mathrm{H}, \mathrm{d}, J=8.8$ )], five methines, three methylenes, and five methyls. The HRFABMS gave a quasimolecular ion peak at $m / z 475.2911\left([\mathrm{M}+\mathrm{H}]^{+}\right.$, calcd 475.2848) suggesting the molecular formula of $\mathrm{C}_{31} \mathrm{H}_{38} \mathrm{O}_{4}$. The ${ }^{13} \mathrm{C}$ NMR spectral data, including DEPT spectra, were in good agreement with the above analysis (Table 1).

The ${ }^{1} \mathrm{H}-{ }^{1} \mathrm{H}$ COSY spectrum of $\mathbf{1}$ showed the following correlations: $\mathrm{H}_{3}-25-\mathrm{H}-24-\mathrm{H}_{2}-26-$ $\mathrm{H}_{2}-27-\mathrm{H}-28 ; \mathrm{H}-20-\mathrm{H}_{2}-21-\mathrm{H}-22-\mathrm{H}-17-\mathrm{H}-18$. The structure of partial unit A (sesquiterpene unit, Figure 1) was indicated by the following long-range correlations in the HMBC spectrum: $\mathrm{H}_{3}-30$ and -31 with $\mathrm{C}-28,-29 ; \mathrm{H}_{3}-25$ with $\mathrm{C}-22,-24,-26 ; \mathrm{H}_{3}-23$ with $\mathrm{C}-18,-19,-20 ; \mathrm{H}-17$ with C-18, -19, -21, -22, -24; and H-18 with C-17, -19, -20, -23.

The remaining ${ }^{1} \mathrm{H}$ and ${ }^{13} \mathrm{C}$ NMR signals of $\mathbf{1}$ were compared with those of hyperolactone $\mathrm{C}$. 4 These data showed good agreement except for the signals of $\mathrm{H}-6\left[\delta_{\mathrm{H}} 3.16(1 \mathrm{H}, \mathrm{dd}, J=6.0\right.$, $1.2)$ in 1 vs $5.99(1 \mathrm{H}, \mathrm{s})$ in hyperolactone $\mathrm{C}, \mathrm{C}-5\left(\delta_{\mathrm{C}} 209.6\right.$ vs 196.6$), \mathrm{C}-6\left(\delta_{\mathrm{C}} 51.9\right.$ vs 100.3$)$, $\mathrm{C}-7\left(\delta_{\mathrm{C}} 89.7\right.$ vs 187.3$)$, and C-11 ( $\delta_{\mathrm{C}} 139.6$ vs 127.7$\left.)\right]$. In 1 , the long-range correlations of H-6 with C-4, $-5,-11$ were observed in the HMBC spectrum. These results clearly indicated that 1 has a saturated C-6/C-7 bond (methine carbon and a quaternary carbon, respectively) rather than the double bond in hyperolactone $\mathrm{C}$. Thus, the structure of partial unit $\mathrm{B}$ (spiro-lactone unit, Figure 1) was elucidated.

The connections of units A (sesquiterpene) and B (spiro-lactone) were established on the basis of the following key correlations: H-6 with H-17 $\left({ }^{1} \mathrm{H}-{ }^{1} \mathrm{H}\right.$ COSY); H-6 with C-17, $-18,-22$, H-17 with C-5, -6, -7, H-18 with C-6, -7 (HMBC). Thus, the direct connections between C-6 and $\mathrm{C}-17, \mathrm{C}-7$ and $\mathrm{C}-18$ formed a cyclobutane ring.

The relative configuration was established from the following NOE correlations: H-6 with $\mathrm{H}-17,-22$, and aromatic protons; $\mathrm{H}-17$ with $\mathrm{H}-18,-22 ; \mathrm{H}_{3}-10$ with aromatic protons. Thus, the structure of 1 was elucidated (Figure 2).

Our postulated biosynthetic pathway of $\mathbf{1}$ from the related sesquiterpene and spirolactone is shown in Scheme 1.

In the search for anti-HIV natural products, various coumarins, terpenoids, and phloroglucinols 5 have been reported to have anti-HIV activity. Accordingly, we evaluated antiHIV activity of this novel compound. Compound $\mathbf{1}$ inhibited HIV replication in H9 lymphocytes with an $\mathrm{EC}_{50}$ value of $0.798 \mu \mathrm{g} / \mathrm{mL}$ and uninfected $\mathrm{H} 9$ cell growth with $\mathrm{IC}_{50}$ values of $>25 \mu \mathrm{g} / \mathrm{mL}$, giving a calculated therapeutic index (TI) value of $>31.3$ (Table 2). Thus, $\mathbf{1}$ can be regarded as a promising new anti-HIV agent with a unique structure and merits further evaluation and analogue design.

Furthermore, we examined the effect of 1 in LPS-induced cytokine production, and it markedly inhibited the LPS-induced production of IL-10, IL-12, and TNF- $\alpha$ (Table 3). These data suggest that $\mathbf{1}$ is a strong inhibitor for cytokines and is worthy of further investigation.

\section{Acknowledgements}

This investigation was supported in part by Grant No. AI-33066 from the National Institute of Allergy and Infectious Diseases (NIAID) awarded to K.H.L. 


\section{References}

1. Cardellina JH II. J Nat Prod 2002;65:1073-1084. [PubMed: 12141880]

2. Murakami K. Tokushima-ken Yakusouzukan 1984:102-103.

3. (a) Nagai M, Tada M. Chem Lett 1987:1337-1340. (b) Tada M, Nagai M. Chem Lett 1989:683-686. (c) Aramaki Y, Chiba K, Tada M. Phytochemistry 1995;38:1419-1421.

4. Aramaki Y, Chiba K, Tada M. Phytochemistry 1995;38:1419-1421.

5. (a) Lee, Thomas TY.; Kashiwada, Y.; Huang, L.; Snider, J.; Cheng, YC.; Lee, KH. Bioorg Med Chem 1994;2:1051-1056. [PubMed: 7773621] (b) Gustafson KR, Cardellina JH, McMahon JB, Gulakowski RJ, Ishitoya J, Szallasi Z, Lewin NE, Blumberg PM, Weislow OS, Beutler JA, Buckheit RW Jr, Cragg GM, Cox PA, Barder JP, Boyd MR. J Med Chem 1992;35:1978-1986. [PubMed: 1597853] (c) Fujioka T, Kashiwada Y, Kilkuskie RE, Cosentino LM, Balls LM, Jing JB, Jazen WP, Chen IS, Lee KH. J Nat Prod 1994;57:243-247. [PubMed: 8176401] (d) Fuller RW, Blunt JW, Boswell JL, Cardellina JH II, Boyd MR. J Nat Prod 1999;62:130-132. [PubMed: 9917299] 

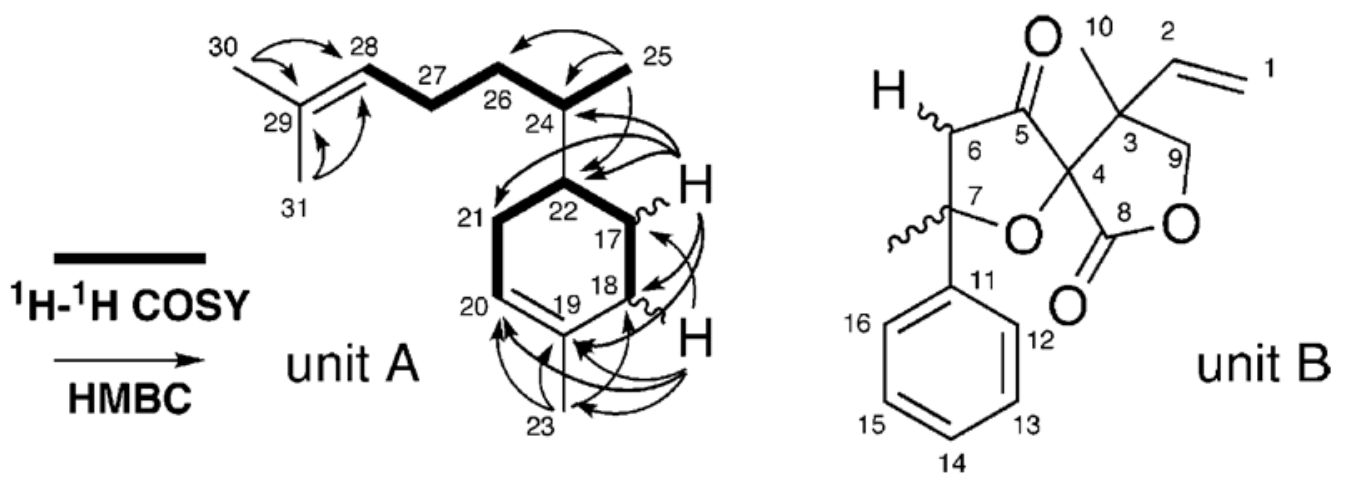

Figure 1.

Partial structures of $\mathbf{1}$. 


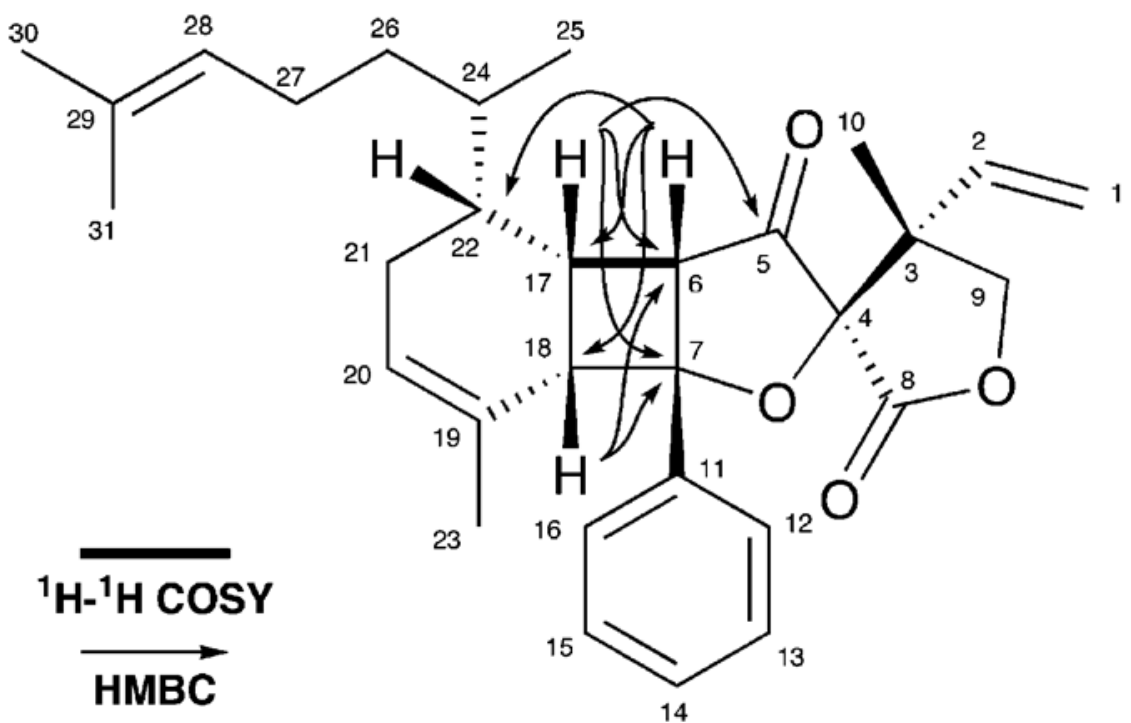

Figure 2.

Biyouyanagin A (1). 


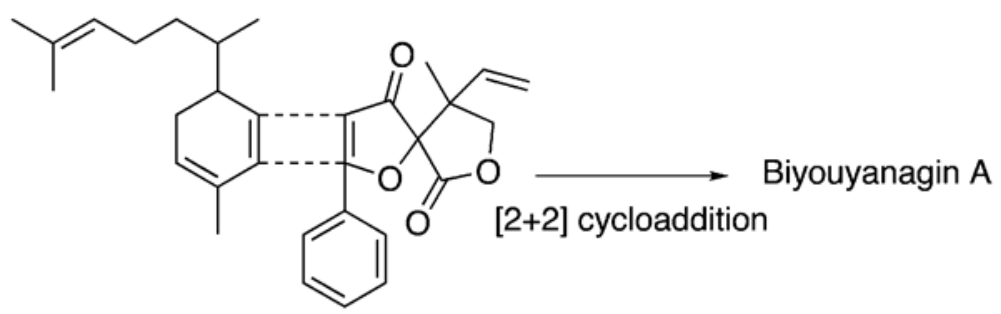

Scheme 1. 
Table 1

NMR Data for $\mathbf{1}^{a}$

\begin{tabular}{|c|c|c|c|}
\hline position & ${ }^{13} \mathrm{C}\left(\delta_{\mathrm{C}}\right)$ & ${ }^{1} \mathrm{H}(\delta \mathrm{H})$ & HMBC $\left({ }^{13} \mathrm{C}\right.$ no. $)$ \\
\hline 1 & 118.4 & $\begin{array}{l}4.80(1 \mathrm{H}, \mathrm{d}, 11.2) \\
4.62(1 \mathrm{H}, \mathrm{d}, 17.6)\end{array}$ & 3 \\
\hline 2 & 134.5 & $5.24(1 \mathrm{H}, \mathrm{dd}, 17.6,11.2)$ & $3,4,9,10$ \\
\hline 3 & 49.0 & & \\
\hline 4 & 93.1 & & \\
\hline 5 & 209.6 & & \\
\hline 6 & 51.9 & $3.16(1 \mathrm{H}, \mathrm{dd}, 6.0,1.2)$ & $4,5,11,17,18,22$ \\
\hline 7 & 89.7 & & \\
\hline 8 & 171.6 & & \\
\hline 9 & 73.7 & $\begin{array}{l}4.71(1 \mathrm{H}, \mathrm{d}, 8.8) \\
3.98(1 \mathrm{H}, \mathrm{d}, 8.8)\end{array}$ & $3,4,8,10$ \\
\hline 10 & 20.1 & $\begin{array}{l}5.98(1 \mathrm{H}, \mathrm{d}, 8.8) \\
1.31(3 \mathrm{H}, \mathrm{s})\end{array}$ & $2,3,4,9$ \\
\hline 11 & 139.6 & & \\
\hline 12 & 125.9 & $7.37-7.26(1 \mathrm{H}, \mathrm{m})$ & 7 \\
\hline 13 & 127.7 & $7.37-7.26(1 \mathrm{H}, \mathrm{m})$ & \\
\hline 14 & 127.8 & $7.37-7.26(1 \mathrm{H}, \mathrm{m})$ & \\
\hline 15 & 127.7 & $7.37-7.26(1 \mathrm{H}, \mathrm{m})$ & \\
\hline 16 & 125.9 & $7.37-7.26(1 \mathrm{H}, \mathrm{m})$ & 7 \\
\hline 17 & 35.9 & $3.01(1 \mathrm{H}, \mathrm{ddd}, 8.4,6.6,6.6)$ & $5,6,7,18,19,21,22,24$ \\
\hline 18 & 50.3 & $3.49(1 \mathrm{H}, \mathrm{d}, 8.4)$ & $6,7,17,19,20,23$ \\
\hline 19 & 131.4 & & \\
\hline 20 & 123.9 & $5.46(1 \mathrm{H}, \mathrm{m})$ & \\
\hline \multirow[t]{2}{*}{21} & 23.5 & $2.09(1 \mathrm{H}, \mathrm{m})$ & \\
\hline & & $1.99(1 \mathrm{H}, \mathrm{m})$ & \\
\hline 22 & 38.8 & $1.73(1 \mathrm{H}, \mathrm{m})$ & 6 \\
\hline 23 & 21.7 & $1.02(3 \mathrm{H}, \mathrm{d}, 1.2)$ & $18,19,20$ \\
\hline 24 & 35.1 & $1.46(1 \mathrm{H}, \mathrm{m})$ & \\
\hline 25 & 16.8 & $0.83(3 \mathrm{H}, \mathrm{d}, 6.4)$ & $22,24,26$ \\
\hline \multirow[t]{2}{*}{26} & 35.0 & $1.45(1 \mathrm{H}, \mathrm{m})$ & $24,27,28$ \\
\hline & & $1.20(1 \mathrm{H}, \mathrm{m})$ & \\
\hline \multirow[t]{2}{*}{27} & 25.9 & $2.02(1 \mathrm{H}, \mathrm{m})$ & \\
\hline & & $1.94(1 \mathrm{H}, \mathrm{m})$ & \\
\hline 28 & 124.6 & $5.11(1 \mathrm{H}, \mathrm{brt}, 5.6)$ & $27,30,31$ \\
\hline 29 & 131.4 & & \\
\hline 30 & 25.7 & $1.70(3 \mathrm{H}, \mathrm{d}, 1.2)$ & $28,29,31$ \\
\hline 31 & 17.7 & $1.61(3 \mathrm{H}, \mathrm{s})$ & $28,29,30$ \\
\hline
\end{tabular}

${ }^{a}$ Measured in $\mathrm{CDCl}_{3}$. Coupling constants given $(J, \mathrm{~Hz})$ in parentheses. 


\section{Table 2}

Anti-HIV Activity of 1

\begin{tabular}{|c|c|c|c|}
\hline compd & $\mathrm{IC}_{50}(\mu \mathrm{g} / \mathrm{mL})$ & $\mathrm{EC}_{50}(\mu \mathrm{g} / \mathrm{mL})$ & TI \\
\hline $\begin{array}{l}\text { biyouyanagin A (1) } \\
\text { AZT }\end{array}$ & $\begin{array}{l}>25 \\
500\end{array}$ & $\begin{array}{l}0.798 \\
0.0021\end{array}$ & $\begin{array}{c}31.3 \\
238,738\end{array}$ \\
\hline
\end{tabular}


Table 3

Inhibitory Effects for Cytokine Release of $\mathbf{1}^{a}$

\begin{tabular}{llcc}
\hline & cytokine production ratio & & TNF- \\
\cline { 2 - 4 } compd & IL-10 & IL-12 & 0.02 \\
biyouyanagin A (1) & & 0.03 & 0.48 \\
prednisolone & 0.14 & 0.48 \\
\hline
\end{tabular}

${ }^{a}$ PBMCs were treated with lipopolysaccharide (LPS) in the presence of $\mathbf{1}(10 \mu \mathrm{g} / \mathrm{mL})$. Prednisolone $(0.3 \mu \mathrm{g} / \mathrm{mL})$ was used as a reference sample.

Data were expressed as ratios to cytokine production induced by LPS. 